Cornell Law Library

Scholarship@Cornell Law: A Digital Repository

Cornell Law Faculty Publications

Faculty Scholarship

2007

\title{
The European Constitution and Its Implications for China
}

Xingzhong Yu

Cornell LawSchool, xy64@cornell.edu

Follow this and additional works at: http://scholarship.law.cornell.edu/facpub

Part of the Comparative and Foreign Law Commons, Constitutional Law Commons, and the Foreign Law Commons

\section{Recommended Citation}

Yu, Xingzhong, "The European Constitution and Its Implications for China" (2007). Cornell Law Faculty Publications. Paper 992. http://scholarship.law.cornell.edu/facpub/992

This Article is brought to you for free and open access by the Faculty Scholarship at Scholarship@Cornell Law: A Digital Repository. It has been accepted for inclusion in Cornell Law Faculty Publications by an authorized administrator of Scholarship@Cornell Law: A Digital Repository. For more information, please contact jmp8@cornell.edu. 


\title{
THE EUROPEAN CONSTITUTION AND ITS IMPLICATIONS FOR CHINA
}

\author{
Xingzhong $\mathrm{Yu}^{*}$
}

\begin{abstract}
The European Constitution is significant not only for the European Union, but also for a developing constitutional system like that of China. The EU constitutional practice may have positive implications on China's constitutional theory and practice. In the wake of the European constitutional achievement, Chinese constitutional scholars need to re-examine their long-held conviction in the indispensable role of the state in constitutional formation and imagination. The EU experience may have provided China with valuable insights and ways to deal with its inherited ethnic problems and improve its institutions on regional autonomy for ethnic minorities. China's own constitutional experiment in Hong Kong may also be enhanced by learning from the EU example.
\end{abstract}

\section{Keywords}

European Constitution, China, Hong Kong, constitutionalism, democracy, sovereignty, subidiarity, regional autonomy

\section{A. INTRODUCTION}

The birth of the Treaty establishing a Constitution for Europe (European Constitution) on 18 June 2004 marked a great step towards more democracy and better protection of human rights in world history. ${ }^{1}$ Not a constitution in the conventional sense, the European Constitution is in large part a restatement of the

* BA (Lanzhou), LLM (Harvard), SJD (Harvard), Associate Professor, School of Law, The Chinese University of Hong Kong; Professor of Law, Northwest University of Politics and Law (Xian). The work described in this article was substantially supported by a grant from the Research Grants Council of the Hong Kong Special Administrative Region, China (Project no CUHK4641/05H [2005] [Law].

${ }^{1}$ See European Parliament resolution on the Treaty establishing a Constitution for Europe of 12 January 2005 (OJ 2005/C 247 E/88). 
ideas, principles and institutions expressed in a series of previously existing basic treaties and agreements, with some newly added content relating to the practical need of the European Union, such as the establishment of the permanent President of the European Council, the creation of a foreign minister for the European Union and the reform of the composition and functions of the European Commission. ${ }^{2}$ It consolidates and simplifies half a century of treaty changes (from Rome to Maastricht, Amsterdam, Nice) allowing Europeans to move from 12 basic treaty acts to a single text. ${ }^{3}$

For the people of the European Union the European Constitution provides a blueprint for a more democratic, effective and transparent community. It clarifies the nature of the European Union, the extent of its powers and its relationship with its Member States. It provides for citizens to actively participate in the decision-making process by an initiative of one million signatures. It also promises more rights for the citizens, containing 54 articles on the fundamental rights provided in the Charter of Fundamental Rights. ${ }^{4}$

For a distant observer, the European Constitution has far more significance than the missions it is expected to accomplish in Europe. It does not only reflect the latest achievement in constitutional reforms of well-structured democracies, but also has enormous implications on the developing constitutional systems such as that of China. As one Chinese author argues, the implications of the European Constitution on China are many and important. ${ }^{5}$ Foremost of these may be on the constitutional thinking which provides guidance for establishing a constitutional framework and designing constitutional institutions. Despite decades of legal and economic reforms, the official Chinese constitutional theory still clings to the view that law and constitution are made by the state, that the nature, authority and function of law can only be understood in the context of a state and that sovereignty is above human rights. The European constitutional experience has provided a new way of thinking that points to a very different direction: The state is not necessarily the only legitimate law-giver and it is questionable that

\footnotetext{
${ }^{2} \mathrm{http} / /$ europa.eu/scadplus/constitution/index_en.htm (accessed on 6 May 2007).

3 The first treaty was the Treaty establishing the European Coal and Steel Community which entered into force on 24 July 1952. Fifty years after entering into force, the Treaty expired as planned on 23 July 2002. Before its expiry, it had been amended on various occasions by the following treaties: Merger Treaty (Brussels 1965), Treaties amending certain financial provisions (1970 and 1975), Treaty on Greenland (1984), Treaty on European Union (TEU, Maastricht, 1992), Single European Act (1986), Treaty of Amsterdam (1997), Treaty of Nice (2001) and the Treaties of Accession (1972, 1979, 1985 and 1994). See "From the ECSC Treaty to the Constitution", http://europa.eu/scadplus/leg/en/s90001.htm (accessed on 6 May 2007).

${ }^{4}$ See the founding principles of the Union http://europa.eu/scadplus/constitution/objectives en.htm\#PRINCIPLES (accessed on 6 May 2007).

5 See Y K Zhou, "Oumeng Falu Shijian Yu Zhongguo Faxue Shida Wenti" (The Legal Experience of the European Union and the Ten Great Issues of Chinese Legal Studies, http://blog.jcrb.com/?4738/action_viewspace_itemid_185590.html (accessed on 12 May 2007).
} 
sovereignty must be more important than human rights. These will have very profound impact on Chinese constitutional consciousness.

At the institutional level China as a multi-nation state can also learn from the experience of the European Union. Various thorny problems exist between the Chinese government and major ethnic groups such as the Tibetans and the Uyghur people who reside in the Western part of China. The European experience may have provided China with valuable insights in dealing with those problems. Principles such as subsidiarity and proportionality could be adopted to achieve the harmony between the ethnic minorities and the Han Chinese. China's own constitutional experiment in Hong Kong may also be enhanced by learning from the European constitutional development.

This article, however, can not address all the important implications that the European Constitution might have on China's constitutional development. It will only deal with some selected aspects of potential implications. After a brief discussion of the European Constitution as a new model of constitutionalism, the article looks at the implications that the European Constitution might have on the constitutional thinking of the Chinese officials and scholars, the regional autonomy for the ethnic minorities and the constitutional reconstruction of the Hong Kong Special Administrative Region (HKSAR).

\section{B. THE EUROPEAN CONSTITUTION AS A NEW MODEL OF CONSTITUTIONALISM}

The history of constitutionalism is the history of human progress, emancipation and civilization. Restricting government's power and protection of individual rights are the core meaning of modern constitutionalism, which originated from the unwritten constitutional tradition of Britain and culminated in the written constitution of the United States of America. The rise of modern constitutionalism represents a kind of reflection of human rationality on the political arrangements of human societies, which expresses a very simple wish through refined institutional arrangements. This simple wish is, expressed in plain language, that the state or government must be responsible to the people, protect the people, and be supervised by the people.

Modern constitutionalism practiced in European and North American countries, drawing inspiration from liberal political and legal theories, in general demonstrates a number of salient features. Substantively, it focuses on such important universal values as democracy, rule of law, human rights and liberty. Formally and institutionally it makes the constitution a social contract between the people and the government which serves as the ultimate authority in the political and legal systems, and plays the role of the supreme standards for legitimacy and validity of such systems. To see the constitution implemented 
ordinary courts or special courts devoted to constitutional enforcement are endowed with the power to guard and interpret the constitution. Practically, constitutional law has been made a branch of law that is actionable and requires specialized knowledge and qualifications for the purpose of implementation.

Despite its many merits, however, modern constitutionalism, as has been pointed out by some scholars, has failed to keep in pace with the economic, technological, and environmental developments which have so profoundly influenced the politics and law in today's world. ${ }^{6}$ It also confines the territory of the constitution to sovereign states. Furthermore, modern constitutionalism represents the sentiments of representative democracy which is the prevalent model of democracy in existence. It, however, has not anticipated the advent of deliberative democracy which requires new constitutional mechanisms to go with it.

It is against this background that one may say that the constitutional practice of the European Union has presented a new model of constitutionalism. First, it has much richer content relating to new economic, technological and environmental issues that have implications for constitutionalism. Second, it has moved beyond state sovereignty, thus completely changing the modern mentality that a constitution is intrinsically linked to sovereignty. Thirdly, it has advanced a new model of constitution-making: A combination of professionalism, parliamentary ratification and popular referendum which embodies the latest trend towards more democracy and better protection of human rights. Fourthly, it is a constitution that defines the Union as a democratic and open "Union of equal citizens and equal states". ${ }^{7}$ This new model of constitutionalism is bound to have significant implications on the constitutional systems of other parts of the world. One of such a systems is that of China which I will discuss in the following pages.

\section{STATE, SOVEREIGNTY AND CONSTITUTION}

Constitutionally, China did not have much to offer to the world. It is believed that even the term "Xian fa" (constitution) is actually a translation from the Japanese language, as many modern terms are. But the word "Xian" did exist in classical Chinese, which had the normative meaning of "law, order or edicts". But it did not have the meaning of a constitution in the modern sense, which lays out the government structure and provides protection of individual rights. There is a

\footnotetext{
6 J M Balkin, "What Is a Postmodern Constitutionalism?" (1992) 90 Michigan Law Review, 1966-1990.

${ }^{7}$ Article I of the European Constitution.
} 
chapter in one of the classics, "SHU JIN" (The Classic of History), believed to be written around the 6th century $\mathrm{BC}$, which resembles something like a constitution. The chapter is called "Hong Fan" (The Great Plan), which contains an exposition of nine categories of government affairs. It was, however, not wellknown or followed by any rulers in the dynastic politics. In any event, there was, if any at all, very little discussion in Chinese classics about individual rights and the idea of using an authoritative document called "Constitution" to lay out the structure of government never emerged.

Modern constitutional discourse in China began in the 1830s when China was witnessing earth-shaking changes of its tradition, but the first Constitution in modern China did not appear until more than 70 years later. ${ }^{8}$ Due to subsequent historic events such as wars with foreign powers, civil wars, many upheavals and revolutions, constitutional discourse also witnessed ups and downs. It was cut short by different revolutions and then resumed after the revolutions because of the reconfiguration of the political power and political ideologies. Since the founding of the People's Republic of China (PRC) in 1949 the constitutional discourse has gone through a metamorphosis from focusing on Marxist ideology in the early 1950s to the promotion of indigenous invention during the Cultural Revolution (1966-1976) to the appeal of liberal constitutionalism in the economic reform and opening-up era since 1978. It is quite apparent that entering the 21st century the constitutional discourse has seen unprecedented prosperity and diversity. ${ }^{9}$

Recent academic signs have shown that Chinese constitutional scholars are divided into groups with some dedicated to the promotion of liberal constitutionalism while others relishing the PRC's own constitutional experience. ${ }^{10}$ However, the dominant legal and constitutional theory backed up by the government still cherishes a particular brand of Marxism which defines law as: the aggregation of the rules of conduct expressing the will of the dominant class and established in legal order, as well as of customs and rules of community life confirmed by state authority, the application whereof is guaranteed by the

\footnotetext{
${ }^{8}$ See W Xie, Cong Xianfa Dao Xianzheng (From Constitutions to Constitutionalism), (Jinan, Shandong People's Press, 2004), 2-4.

${ }^{9}$ For instance, in 2005 alone more than a dozen conferences were held nationwide, about fifteen books and numerous articles on constitutional law were published, which discussed various topics of constitutional law. See Han Dayuan, "Constitutional Scholarship in 2005", at http://www.calaw.cn/include/shownews.asp?newsid=6461 (accessed on 6 May 2007).

${ }^{10}$ Many well-known works on liberal constitutionalism have been translated into Chinese. Bruce Ackerman's We the People, Ronald Dworkin's many books, Hayek's The Constitution of Liberty and other works, Lawrence Tribe's Constitutional Choice, and so on are among the reference books for postgraduate students of legal theory and constitutional law. Not only have their books been translated into Chinese, they are also systematically studied as important constitutional thinkers.
} 
coercive force of the state to the end of safeguarding, making secure and developing social relationships and arrangements advantageous and agreeable to the dominant class. ${ }^{11}$ This definition was written into law textbooks in the former Soviet Union and introduced into China in the early 1950s and was hailed as the authentic Marxist concept of law by Chinese legal scholars. ${ }^{12}$ More than fifty years later, some key Chinese constitutional scholars still believes that that definition represents truth and that the general nature of law also applied to the Constitution. ${ }^{13}$

At the practical level the Chinese constitutional system, modeled on written constitutions of the major countries of the world, with the National People's Congress (NPC) concurrently being the supreme power organ and the legislature, is quite sensitive to state sovereignty and the central power. The PRC has had four formal constitutions (1954, 1975, 1978 and 1982) and a provisional constitutional document called Common Program (1949). The 1982 Constitution, which is currently in force, has been amended four times, in April 1988, March 1993, March 1999, and March 2004 respectively, to reflect the changing circumstances since the economic reforms started. These constitutions, unlike their counterparts in liberal societies, serve as the programs of the party/state for ideological guidance and as political documents that reflect government policies.

As discussed previously, the official Chinese legal and constitutional theory holds that the validity of law lies in the fact that it is made by the state and reflects the will of the state. On this view, the authority of law is derived from the authority of the state and there is no law beyond the state. The making of the European Constitution shows that law could exist in a non-state context. The law does not necessarily reflect the will of the state, even though a state can be a participant in the law-making process. The authority of law, instead of resting on the state, roots itself in a mega-structure that overlooks the states. The European Constitution and laws, as outcomes of collective efforts of all Member States, are not made by any particular member state and do not reflect the interest or will of any particular state. States are in fact subject to the EU laws and the European Constitution. Judges of the European Court of Justice are independent and do not represent any Member State. The court's decisions, however, must be honored by all Member States.

China imported the concept of sovereignty from the West and has so far made very good use of it. It has been regarded as absolute, indivisible and supreme for

\footnotetext{
${ }^{11}$ V I Lenin ea, Soviet Legal Philosophy, H W Babb (tr) (Cambridge, Mass, Harvard University Press, 1951), 336.

12 See S Z Zhang, "An Yang Weixinsiji dui Falu Kexue de Zhuoyue Gongxian" (A Y Vyshinsky's Eminent Contribution to the Legal Science), (1955) 2 Zhengfa Yanjiu (Political and Legal Studies), 51.

${ }^{13} \mathrm{C}$ D Xu, Xuer Yanxian (Studies in Constitutional Law), (Beijing, Law Press, 2000), 434.
} 
maintaining the one-party rule of the Chinese Communist Party (CCP) and the PRC government. When China was criticized for its bad records of human rights, the government justified its behavior by arguing that sovereignty comes before human rights and the latter is the internal affair of a country that foreigners should not interfere with. The European Constitution has made it very clear that sovereignty can not trump human rights. The European Human Rights Court stands above the Member States in protecting the rights of the individuals of the Member States. If the EU is viewed as a sovereign entity, then sovereignty can be divided externally and internally and shared by different institutions, but human rights are absolute. Under the European Constitution no state should ignore or violate human rights of any individual. The European experience obviously puts the Chinese mentality on sovereignty and human rights on trial, not only because it reflects the general trend of world constitutionalism, but also because Europe is the place where concepts like "sovereignty" and "human rights" originate.

\section{SUBSIDIARITY AND CHINA'S AUTONOMOUS REGIONS}

\section{Regional Autonomy for Ethnic Minorities in China}

To date, the Chinese government has identified 56 ethnic groups in China. ${ }^{14}$ As the majority of the population belongs to the Han ethnic group, China's other 55 ethnic groups are customarily referred to as the ethnic minorities. According to the fifth national census conducted by the Chinese government in 2000 , the population of all the 55 ethnic minority groups totaled 104,49 million, accounting for 8,41 percent of the total population of China. ${ }^{15}$

China has a landmass of 9,6 million square kilometers, making it almost as large as the combined nations of Europe. Although small in number, the peoples of the various ethnic minorities inhabit 50 to 60 percent of the country's territory. Ethnic minorities live in a wide expanse of land with a sparse distribution of population. Many minority peoples have traditionally established their villages in mountainous and pastoral areas, on high plateaus and in deep forests. The areas

\footnotetext{
14 These are the Han, Mongolian, Hui, Tibetan, Uygur, Miao, Yi, Zhuang, Bouyei, Korean, Manchu, Dong, Yao, Bai, Tujia, Hani, Kazak, Dai, Li, Lisu, Va, She, Gaoshan, Lahu, Shui, Dongxiang, Naxi, Jingpo, Kirgiz, Tu, Daur, Mulam, Qiang, Blang, Salar, Maonan, Gelo, Xibe, Achang, Pumi, Tajik, Nu, Ozbek, Russian, Ewenki, Deang, Bonan, Yugur, Jing, Tatar, Drung, Oroqen, Hezhen, Moinba, Lhoba and Jino.

${ }^{15}$ Regional Autonomy for Ethnic Minorities in China, Government White Paper issued by the Information Office of the State Council of the People's Republic of China, February 2005, Beijing, Preface.
} 
they inhabit have a wide range of products and abundant mineral resources, and are also strategically important as border regions for the whole country.

Ethnic problems in China have a long history. It was recorded in Chinese classics that even before the unification of China under the First Emperor of Qin in $221 \mathrm{~B} \mathrm{C}$, the distinction between Han people and the minority peoples was already made explicit, with the former as superior and the latter as inferior. The Han people who inhabited the central parts of China were called the Huaxia or Xia people, while the minority people who inhabited the peripheral areas were called Yi, implying barbarity and backwardness. For the rulers of various dynasties in Chinese history the affairs between the Xia people and the Yi were always important. There were times when the minority people ruled China, like Yuan dynasty (1206-1368 AD) and Qing Dynasty (1644-1911 AD), but mostly China was ruled by Han people.

Since 1949 the PRC government has implemented what it has called "regional autonomy for ethnic minorities". Over the years this arrangement has witnessed ups and downs and gradually evolved into an institution which has taken on certain characteristics of its own, even though there is still a large gap between the ideal and the practice. Regional autonomy for ethnic minorities in China is regulated by three types of normative instruments: the PRC constitution, the Ethnic Regional Autonomy Law and other relevant laws, and the party/state policies. The 1984 Ethnic Regional Autonomy Law was the first formal law of the PRC systematically regulating ethnic affairs, which was based on the 1982 PRC Constitution and the party/state policy on ethnic affairs. Although work on ethnic affairs has always been high on the party/state's political agenda, with the exception during the Cultural Revolution, such affairs were traditionally handled by policy, rather than law.

Under the current arrangement the central government exercises control over all provinces, autonomous regions and other administrative regions. Selfgovernments of the autonomous regions derive their powers from the unitary state. Local legislatures must defer to the state legislature, the NPC. Local governments follow instructions of the State Council. Local courts are part of the whole judicial apparatus of the state and so are the local procuratorates. In essence, the relationship between the institutions at the national level and those at the level of autonomous areas is of a vertical nature, with the national institutions at the controlling position.

As the Ethnic Regional Autonomy Law is a basic law that sets out the general framework for establishing the autonomous areas, delineating powers and functions of autonomous governments and reiterating in the form of a legal document the party/state policy on ethnic affairs and the relationships between the central government and the autonomous areas, it is mainly composed of what 
H L A Hart termed "secondary rules" which are power-conferring rules that do not provide for remedies or liabilities for failure to comply. ${ }^{16}$ The enforcement of this law, therefore, rests entirely on the conscience and awareness of the departments concerned. If a state organ fails to implement such a law, there is no legal basis to hold such an organ responsible and hence no remedy can be sought. For instance, article 65 of the revised Ethnic Regional Autonomy Law provides that while exploiting resources and undertaking construction in an autonomous area of ethnic minorities, the state shall give consideration to the interests of these areas, make arrangements favorable to the economic construction there and pay proper attention to the productive pursuits and the life of the ethnic minorities there. If a state organ at higher level does not comply with this provision, the minority area concerned does not have a legal recourse for coerced enforcement. In reality, the state often failed to take into consideration the interests of the local ethnic minorities when exploiting local resources. ${ }^{17}$ In addition, a basic law like this is constitutional by nature and as such, like the PRC Constitution itself, it is hardly actionable. Past experience has shown that the Ethnic Regional Autonomy Law has rarely been cited to decide court cases.

\section{The Relevance of the Principle of Subsidiarity}

One of the implications that the European Constitution may have on the Chinese system of ethnic regional autonomy is the adoption of the principle of subsidiarity, which, although also used in Constitutions of other countries like that of the United States, now serves as a fundamental principle of the European Constitution. ${ }^{18}$ This important principle has a very simple meaning: Matters ought to be handled by the smallest (or, the lowest) competent authority. As used in the political and administrative sense, it means that a central authority should have a subsidiarity function, performing only those tasks which cannot be performed effectively at a more immediate or local level.

Even though China is not a federalist country, nor a mega-structure like the EU, as far as the original meaning of the principle of subsidiarity is concerned, China may well benefit from it. Adopting this principle may better facilitate China's ethnic regional autonomy system, giving more autonomy to the ethnic groups and local communities which, as has been acknowledged by the PRC

\footnotetext{
${ }_{17}^{16}$ H L A Hart, The Concept of Law, (Oxford University Press, 2nd edn 1994), 100-110.

17 T Luo, Z S Liu, and S M Li, Wanshan Minzu Quyu Zizhi Fa Wenti Yanjiu (Studies on Improving the Law on Regional Autonomy of Ethnic Minorities), (Chengdu, Sichuan People's Publishing House, 1997), 27.

${ }^{18}$ Subsidiarity was established in EU law by the Treaty of Maastricht, signed on 7 February 1992 and entered into force on 1 November 1993. The present formulation is contained in article 5 of the European Constitution.
} 
government, have diverse and rich cultural and legal traditions. As individual persons and local communities have more urgent and clearer understanding of what they need-and what they do not need-than any institutions which sit far away from their communities, the practice of subsidiarity may bring about more realistic strategies and proposals for solving local problems, thus unleashing inestimable creativity and imagination for a harmonious society in which different human cultures and interests are adequately presented and equally protected.

If the principle of subsidiarity were adopted, the central government of the PRC would not have to make decisions for China's five major autonomous regions and hundreds of autonomous prefectures and counties, which make up half of its territory, unless these autonomous areas do not have the competence to do so for themselves. This has a dual advantage: it helps to reduce the workload of the central government and at the same time it allows more autonomy to the ethnic minority areas. Because of the size of China, the central government, however effective, can not deal with the multitude of problems that it faces every day, especially when China is undergoing drastic economic and social transformation at present. The minority areas, in fact, have already lagged behind in China's economic reform drives. Compared with costal regions and even some inner provinces, minority areas are underdeveloped and much poorer, even though these areas are rich in natural resources.

Adopting the principle of subsidiarity is also in line with the Chinese government's policy of providing assistance to the minority areas. As has been discussed above, one of the major principles of the Ethnic Regional Autonomy Law holds that the state has the obligation to assist the minority areas as long as they remain part of China. As a principle, provision of assistance to minority areas was already adopted in the 1946 Constitution of the Nationalist Government. (articles 168 and 169). ${ }^{19}$ It was also retained and reiterated by the major political documents since the founding of the PRC (For instance, article 53 of the Common Program; article 72 of the 1954 Constitution of the PRC). This principle even survived the Cultural Revolution and returned in the 1975 and 1978 Constitutions. The 1982 Constitution has more elaborative stipulations on providing assistance to the autonomous areas, which were further detailed in the 1984 Ethnic Regional Autonomy Law.

${ }^{19}$ Luo ea, Wanshan Minzu Quyu Zizhi Fa Wenti Yanjiu, supra, n 17, 27. 


\section{E. IMPLICATIONS FOR HONG KONG'S CONSTITUTIONAL ORDER}

\section{Hong Kong's Constitutional Development}

China's own constitutional experiment in Hong Kong-regional constitutionalism-may also be enhanced by learning from the European constitutional development. The constitutional story of Hong Kong has been quite unique. After seizing Hong Kong in 1842, the British government through its symbolic authority, the Queen, issued a series of prerogative instruments, stipulating the legal status, governing Constitution, and the institutional division of labor and the scope of powers in Hong Kong. ${ }^{20}$ These prerogative instruments were by nature constitutional documents, even though they were not explicitly termed as such. If the Royal Charter only made it clear that Hong Kong became a colony of Britain, then the Letters Patent set out the structure of Hong Kong's government and its organizational forms. It also established the Executive Council and the Legislative Council and set out the scope of power of the Governor.

The legal landscape in Hong Kong after 1997 when China resumed sovereignty has been reconfigured in order to accommodate the political change. Hong Kong law previously in force has largely been kept with a few alterations. ${ }^{21}$ The most significant change, perhaps, is the adoption of the Basic Law of the Hong Kong Special Administrative Region (HKSAR) of the People's Republic of China (Basic Law). The Basic Law was a fundamental law drafted by a group of persons selected by the Central Government and enacted by the NPC in accordance with the PRC Constitution and the Sino-British Joint Declaration of 1985. The Basic Law stipulates the institutions practiced in Hong Kong and serves as the foundation for its legal system. The structure of the Basic Law resembles that of a constitution, which records the institutional arrangements of the HKSAR, lays out the structure of the Hong Kong government and provides fundamental rights and duties for Hong Kong residents. Although it was intended to function as the constitution for Hong Kong, it was not given the name of a "Constitution" because doing so would have made Hong Kong look like an

\footnotetext{
${ }^{20}$ These documents include the Royal Charter issued on April 5, 1843, which declared that Hong Kong became a colony of the Great Britain; Kowloon City Order in Council issued on February 4, 1861; New Territories Order in Council issued on October 20, 1898; the Letters Patent issued on April 20, 1917, and the Royal Instructions which were supplements to the Letters Patent issued in the name of the Royal Court to the Governor and the colonial government of Hong Kong.

${ }^{21}$ For instance, article 8 of the Basic Law provides that "the laws previously in force in Hong Kong, that is, the common law, rules or equity, ordinances, subordinate legislation and customary law shall be maintained, except for any that contravene this Law, and subject to any amendment by the legislature of Hong Kong Special Administrative Region.”
} 
independent state. It is called Basic Law because it is made by the NPC intended to have legal effect like that of a national law subject to PRC constitution.

Since 1997 Hong Kong's constitutional development has been marked by a number of constitutional controversies. The right of abode cases inaugurated a new constitutional practice and consciousness, which tested the new constitutional order founded on the Basic Law and the existing Hong Kong law. The Court of Final Appeal (CFA) decisions on the right of abode cases and the NPC Standing Committee's interpretation of article 22 and 24 of the Basic Law competed for the ultimate authority in Hong Kong's legal order and cast shadows over the possibility of judicial independence in Hong Kong after $1997 .^{22}$ Controversies over article 23 legislation sharpened Hong Kong people's vigilance against any abridgement of their freedoms. Controversies over the Basic Law provisions on the election of the Chief Executive and the members of the Legislative Council beyond 2007, reflected different attitudes towards universal suffrage and greater democracy. All these controversies have contributed one way or another, to Hong Kong's constitutional development and increased Hong Kong people's constitutional consciousness. At the same time, and more quietly, Hong Kong courts, especially the CFA, have made judicial decisions implementing the provisions of the Basic Law that are less controversial and more concerned with the interests of small individual groups or institutions. ${ }^{23}$ The government, too, has taken a proactive attitude towards the implementation of the new constitutional order by various means. For instance, it has set up a task force to act as an intermediary between Hong Kong people and the Central Authorities, conveying the opinions of Hong Kong people to the Central Authorities, and explaining the concerns of the Central Authorities to Hong Kong people. Various social sectors, concerned groups, intellectuals, professionals and the general populace have demonstrated an unprecedented interest and enthusiasm in promoting Hong Kong's constitutional order. In sum, all those developments have ushered in a constitutional movement and Hong Kong is now constitutionally engaged.

\section{Implications of the European Constitution}

Now under the new constitutional framework, Hong Kong as part of the PRC is confronted with the issues that concern its relationship with the central government on the Chinese Mainland. Many a time questions concerning Hong Kong's constitutional position and principles such as autonomy, the rule of law,

${ }^{22}$ See Johannes M M Chan ea (eds) Hong Kong's Constitutional Debate (Hong Kong, Hong Kong University Press, 2000). This useful book contains detailed discussions on the CFA decisions and has an appendix of the relevant documents.

${ }^{23} \mathrm{See}$ http://www.info.gov.hk/basic_law/fulltext/, Basic Law related judgments (accessed on 12 May 2007). 
freedoms and human rights have been asked. In fact China's own constitutional practice in Hong Kong employed the principle of subsidiarity unconsciously. Under the "one country, two systems" arrangement, Hong Kong has retained its capitalist system and common law tradition, and enjoys high autonomy. Almost all its major decisions are made by the HKSAR government; the central government which assumes the defense and diplomatic responsibilities for Hong Kong, usually stays behind the stage and rarely interfered with Hong Kong's daily affairs. When Hong Kong needs help, for instance, to boost its economy, the central government acted on Hong Kong government's request and provided assistance. This is obviously an example of using the principle of subsidiarity.

If the European Constitution has made the state a non-essential element for constitutionalism by its very supra-state nature, Hong Kong's constitutional development confirmed the non-essential nature of the state for constitutionalism by showing that even a small part of a state can have its own constitutional law and experience. The European Constitution is a constitution outside a state and Hong Kong's Basic Law is a constitution within a state. Both experiences have separated sovereignty from constitutionalism-representing two examples of a new model of constitutionalism from different parts of the world with different magnitude of significance and different cultural traditions. The European Constitution has provided very strong theoretical and practical support for Hong Kong's constitutional development, having successfully dispelled the skepticism about Hong Kong's constitutional status.

Under the European Constitution the European Court of Justice exercises the ultimate power of constitutional interpretation, but on routine basis the actual enforcement and interpretation of the European Constitution are effectuated by national supreme courts (or constitutional courts or the institutions of the same nature). This multi-interpretive arrangement reflects the pragmatic attitude of the EU governance. The European Court of Justice is simply not in a position to engage in daily enforcement and interpretation of the European Constitution in the Member States. The same structure can be found in Hong Kong's constitutional framework. The NPC is the supreme power organ in the PRC, which has enacted the Basic Law and articulated the principles of "one country, two systems". Its permanent working institution, the Standing Committee of the NPC, has the ultimate interpretive power of the Basic Law, but can not effectively exercise it, because it is not an adjudicative body and because it is far removed from Hong Kong's reality. For the sake of efficiency the NPC Standing Committee has delegated the interpretive power of the Basic Law to the Court of Final Appeal (CFA) of the HKSAR. Furthermore, future constitutional development in Hong Kong requires coordination of the Basic Law provisions and the common law constitutional principles and practice. It is not the NPC Standing Committee but the CFA that is capable of doing that job. The Basic Law, however, does not grant the power to interpret the Basic Law regarding affairs 
concerning central authority and the relations between the central government and the HKSAR. That power was retained by the NPC Standing Committee. The purpose of having that power reserved for the NPC Standing Committee was to deal with the issues arising from inter-institutional conflicts between Hong Kong and the central government of the PRC.

Connected to the multi-interpretive authorities is the sharing of the power of constitutional review. Under the European Constitution the national supreme courts or constitutional courts (or the institutions of the same nature) are responsible for bringing in line with the European Constitution the national legislation or administrative acts made by respective Member States. The European Court of Justice, however, has the final say of the matters requiring constitutional review. This two-tier review system combines what is usually termed "centralized review" with "decentralized review". Centralized review of the unconstitutionality of a legislative act or an administrative act is often conducted by a non-judicial institution or a specifically established group of people or institution, like a constitutional court or the legislature of the state. Decentralized constitutional review is done by ordinary courts, which is often practiced in common law systems. China in theory practices the former while Hong Kong practices the latter. The new constitutional order of Hong Kong has made many signs of adopting the same structure of combining the central and decentralized review, but the issue is yet to be solved. The NPC Standing Committee theoretically should be the final authority for constitutional review in Hong Kong. But it seems more practical to argue for the CFA to assume that power in Hong Kong because that power has traditionally been exercised by common law courts in other jurisdictions. Following the example of the European Constitution, a two-tier constitutional review structure in Hong Kong is imaginable, which could combine both centralized and decentralized review mechanisms.

\section{F. CONCLUSION}

The European Constitution, even though yet to be ratified and put into practice, has already set an example for newly developing constitutional systems. In the above I discussed its possible implications for the Chinese constitutional system which is constantly envolving and my discussion covers only some obvious and limited aspects in the Chinese system on which the European Constitution may have implications. I believe there could be even more significant and profound implications on the Chinese constitutional system, as our research on these issues deepens and when the European Constitution is actually in force. The implications are of course not limited to the constitutional system like that of China. As a new model of constitutionalism, the European Constitution is bound 
to have far-reaching influence on the ongoing world constitutional movement. The principles of subsidiarity and proportionality, much the same as the principles of separation of powers and checks and balances, will become catch phrases in the world lexicon of constitutional law. But it remains to be seen how the constitutional institutions envisaged by the European Constitution fare in the real world of politics and law. 
